\title{
MiniReview
}

\section{In Vitro Models of Vasculogenesis and Angiogenesis}

\author{
Bruno Vailhé, Daniel Vittet, and Jean-Jacques Feige \\ Institut National de la Santé et de la Recherche Médicale, Laboratoire de Biochimie des Régulations Cellulaires \\ Endocrines, Département de Biologie Moléculaire et Structurale, Commissariat à l'Energie Atomique, Grenoble, \\ France
}

$V$ asculogenesis and angiogenesis are the fundamental processes by which new blood vessels are formed (Carmeliet, 2000; Risau, 1997; Risau and Flamme, 1995). Vasculogenesis is defined as the differentiation of precursor cells (angioblasts) into endothelial cells and the de novo formation of a primitive vascular network, whereas angiogenesis is defined as the growth of new capillaries from pre-existing blood vessels (Risau, 1997). In the embryo, blood vessels form through both vasculogenesis and angiogenesis. In the adult, the transient formation of new blood vessels is only observed under certain physiological situations (eg, in the female reproductive tract under control of the oestrous cycle, in the placenta during pregnancy, or during wound healing), and occurs mainly through angiogenesis. Dysregulated angiogenesis has been implicated in the pathogenesis of numerous diseases including vascular retinopathies, rheumatoid arthritis, and cancer (Folkman, 1995). The pioneering work of Folkman and his colleagues has convincingly established the concept that tumor development is dependent upon neoangiogenesis and has paved the way for the identification of several angiogenic molecules, including the fibroblast growth factor (FGF) and vascular endothelial growth factor (VEGF) families (Folkman and Shing, 1992). However, the recent characterization of circulating bone marrow-derived endothelial progenitor cells in the blood of adult animals and the demonstration of their incorporation into pathological neovascular foci indicate that vasculogenesis may also participate in pathological neovascularization (Isner and Asahara, 1999). Although major progress has been made during the last decade, our understanding of the molecular mechanisms of these processes is still incomplete.

Gene knock-out experiments have emphasized the pivotal roles played by VEGF, VEGF receptor 2 (VEGF-

Received September 13, 2000.

Address reprint requests to:

Dr. Bruno Vailhé, Laboratoire de Biochimie des Régulations Cellulaires Endocrines, INSERM Unite 244, DBMS/BRCE, CEA/G, 17 rue des Martyrs, 38054 Grenoble Cedex 9, France. E-mail: bvailhe@cea.fr
R2, also called flk-1 and KDR in mice and humans) and VEGF-R1 (also called flt-1) during embryonic vasculogenesis (Carmeliet et al, 1996; Ferrara et al, 1996; Fong et al, 1995; Shalaby, 1995). Heterozygous mice lacking one copy of the VEGF gene die in utero at E10.5, with aberrant blood vessel formation in the yolk sac and the embryo (Carmeliet et al, 1996; Ferrara et al, 1996). Mice lacking the VEGF-R2 gene present early defects (at E8.5) in angioblastic lineages (Shalaby, 1995). VEGF-R1 appears to play a role slightly later in embryonic vasculogenesis, because mice lacking the VEGF-R1 gene produce angioblasts but fail to correctly assemble endothelial cells into functional blood vessels and die at E8.5 (Fong et al, 1995). Thus, during embryonic angiogenesis, VEGF-R2 and VEGF-R1 are required sequentially in that order. In addition, several transcription factors, including ets-1 and Vezf1, have been proposed to play a role in the engagement of angioblasts toward the endothelial cell fate.

Two distinct mechanisms of angiogenesis have been described: sprouting and intussusception. Intussusceptive angiogenesis is caused by the insertion of interstitial cellular columns into the lumen of preexisting vessels. The subsequent growth of these columns and their stabilization results in partitioning of the vessel and remodeling of the local vascular network (Risau, 1997). Sprouting angiogenesis entails two successive phases: neovessel growth and neovessel stabilization. During the initial phase, the following sequence of events usually occurs: dissolution of the basement membrane of the "mother" vessel and its surrounding interstitial matrix, migration of endothelial cells in this created space toward the angiogenic factor, proliferation of endothelial cells behind the front of migration, lumen formation within the endothelial sprout, and formation of loops by anastomoses of sprouts. The stabilization phase consists of arrest of endothelial cell proliferation, reconstruction of a basement membrane around the neocapillary, and investment and coverage of the immature capillary with pericytes. Both phases are equally important because, in the absence of vessel 
stabilization, the immature capillary will rapidly undergo apoptosis and regress (Benjamin et al, 1998). Whereas VEGF is important for the growth phase, transforming growth factor (TGF)- $\beta$, platelet-derived growth factor (PDGF)-BB, angiopoïetin-1, and their respective receptors are essential for the stabilization phase, as confirmed by both functional knockout of their genes in vivo and a number of in vitro observations (Beck and D'Amore, 1997). Invalidation of the genes encoding these factors and their receptors is lethal between E10.5 and birth as a result of edemas and hemorrhages, indicating that they are essential for vascular bed maturation. Several integrins are also involved in vascular morphogenesis (Bader et al, 1998). $\alpha v \beta 3$, which is weakly expressed in quiescent blood vessels and highly increased in angiogenic vessels, is probably an important participant in tumor angiogenesis (Brooks et al, 1994a, 1994b, 1995). However, its role is less crucial during embryonic angiogenesis, as indicated by the viability of integrin $\beta 3$ null mice (Hodivala-Dilke et al, 1999). Interendothelial adhesion molecules, such as vascular endothelial (VE)-cadherin (Carmeliet et al, 1999; Gory-Faure et al, 1999) and platelet-endothelial cell adhesion molecule (PECAM)-1 (DeLisser et al, 1997; Yang et al, 1999), also appear to be essential to the angiogenesis process.

As a common theme in biology, the action of the pro-angiogenic molecules listed above is counteracted by that of angiostatic factors. This has led to the concept of the angiogenic balance, according to which, overexpression of angiostatic or angiogenic factors controls endothelial quiescence or active angiogenesis, respectively (Iruela-Arispe and Dvorak, 1997). In vitro angiogenesis assays have been highly useful for the identification of a number of these factors and the characterization of their mechanism of action (Auerbach and Auerbach, 1994). Both natural proteins containing an angiostatic motif, such as the thrombospondin type I repeat (Adams and Tucker, 2000), and tumor-secreted proteolytic fragments, such as angiostatin and endostatin (Sage, 1997), have been identified as potent in vitro and in vivo angiogenesis inhibitors and have drawn attention as potential therapeutic agents (Klohs and Hamby, 1999). Several in vitro observations have shown that distinct angiostatic factors commonly act through induction of endothelial cell apoptosis, although via distinct molecular mechanisms (Claesson-Welsh et al, 1998; Jimenez et al, 2000).

Thus, if the activity of key molecules implicated in vascular morphogenesis needs to be evaluated through the gene invalidation approach, much can still be learned about their mechanism of action from in vitro assays (Ashton et al, 1999; Pelletier et al, 2000; Vittet et al, 1997). These usually encompass only one or a few specific steps of the whole morphogenetic processes. They nevertheless allow the distinction between direct (acting via endothelial cell receptors) and indirect (acting through a paracrine pathway) angiogenic factors. For example, cell proliferation can be assessed in vitro by the quantitation of tritiated thymidine incorporation into DNA of capillary endothelial cells or simply by cell counting. Migration assays consist primarily of the use of standard or modified Boyden chambers. Linear endothelial cell migration assays, such as those measuring the repair of a wound made across an endothelial cell monolayer (Ashton et al, 1999; Hoying and Williams, 1996), are also widely used. Proteolysis can be tested using zymographic assays (Pepper et al, 1987). Endothelial cell apoptosis can be measured either by the TUNEL (terminal desoxynucleotidyl transferase-mediated dUTP-biotin nick end-labeling) method or by the quantitation of specific markers such as caspases. Although these assays are very useful reporters for specific steps of the angiogenic process, they do not correctly model the complex interplay of multiple factors that is necessary for vessel development.

In contrast, several integrated assays have been developed that better recapitulate the multistep angiogenic and vasculogenic processes. Moreover, they offer the possibility of evaluating the effects of angiogenic and angiostatic factors at lower cost and experimental complexity than those of in vivo assays.

We will review here in detail the diverse in vitro models of vasculogenesis and angiogenesis that have been described to date and will critically address the advantages and limitations of each of them. Because of space constraints, we have chosen to focus our interest on morphogenesis models, ie, models in which endothelial cells undergo a morphological differentiation process leading to the formation of vascular structures. We have also attempted to highlight unresolved biological questions which may be amenable to such studies.

\section{Vasculogenesis Models}

As stated above, vasculogenesis occurs during both embryonic development and adult vascular growth by angioblast mobilization (reviewed in Carmeliet, 2000). Several in vitro systems have been developed for investigating the cellular events of vasculogenesis. Among them, embryo-derived mesodermal cell culture and embryonic stem (ES) cell differentiation assays enable researchers to investigate vasculogenesis virtually as it occurs in the embryo in vivo. Adherent cultures of dissociated cells from quail blastodiscs have been reported to generate both hematopoietic and endothelial cells that aggregate into characteristic blood islands and give rise to vascular structures in long-term culture (Flamme and Risau, 1992; Flamme et al, 1993). Vasculogenesis can also be observed when the same quail blastodisc cells are grown in suspension and form three-dimensional spherules (Krah et al, 1994). However, the formation of vascular structures in quail blastodisc cultures is strictly dependent on the presence of fibroblast growth factor-2 (FGF2) (Flamme and Risau, 1992; Flamme et al, 1993; Krah et al, 1994).

Perhaps the most promising system that has emerged in the past decade is the murine ES cellderived embryoid body (EB) formation assay. This 


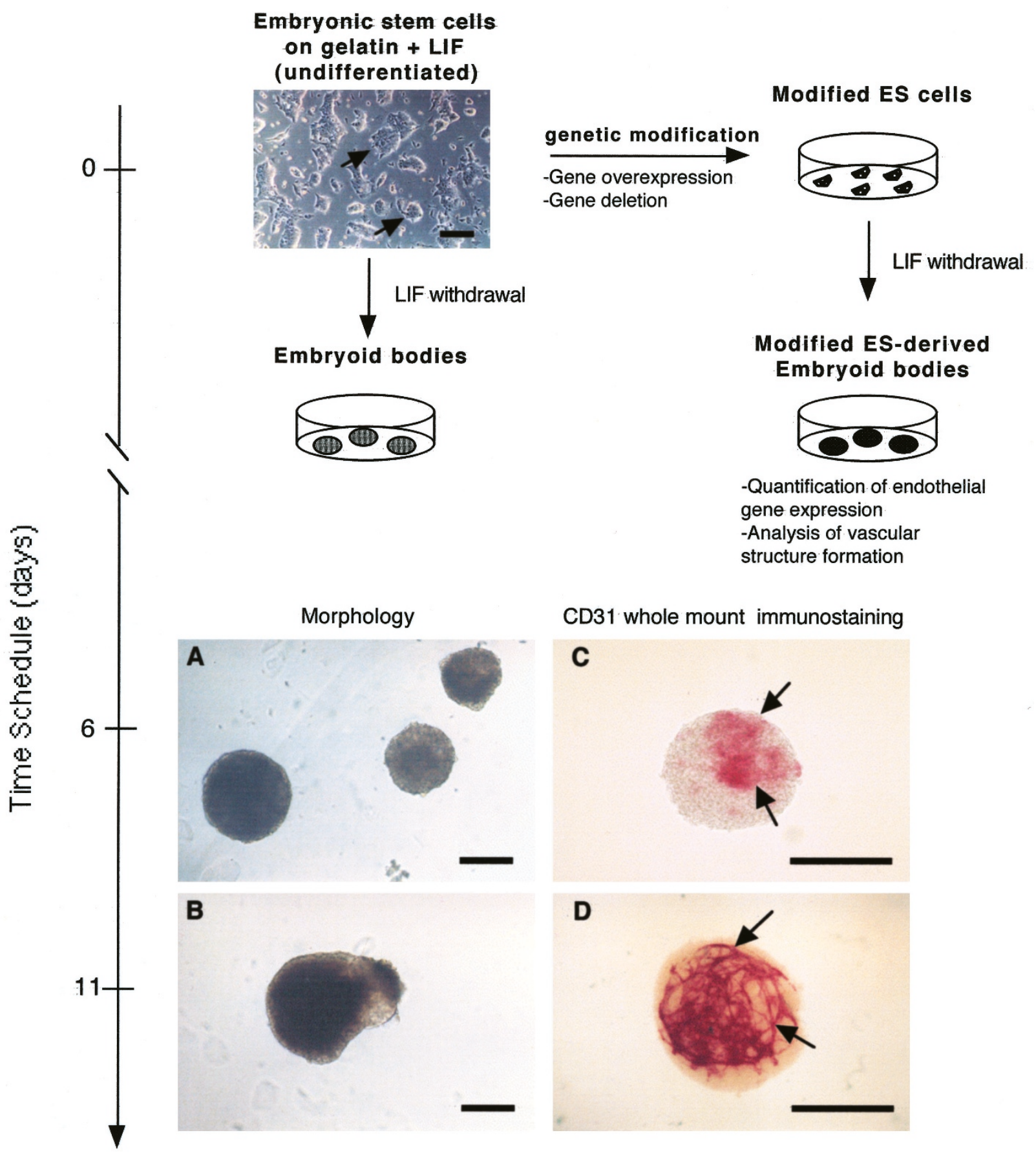

\section{Figure 1.}

Schematic representation of in vitro embryonic stem cell technology as a model for vasculogenesis analysis. Embryonic stem (ES) cells, maintained undifferentiated in the presence of leukemia inhibitory factor (LIF) (see cell clumps as indicated by arrows), can undergo genetic manipulation leading to gene deletion or overexpression. Undifferentiated ES cells are induced to differentiate into complex embryoid bodies (EBs) after withdrawal of LIF from the culture medium. The morphology of 6-day- and 11-day-old EBs is shown by light microscopy (Panels A and B). During embryoid maturation, endothelial differentiation and vascular morphogenesis can be monitored. Panels $C$ and D illustrate platelet-endothelial cell adhesion molecule (PECAM) whole mount immunostaining of EBs at Day 6 and Day 11. Arrows point to PECAM-positive cell clusters (Day 6) or vascular structures (Day 11), respectively. Scale bar $=200 \mu \mathrm{m}$.

model system, whereby a primitive vascular plexus is formed (Fig. 1), provides an attractive tool for dissecting the mechanisms involved in the vasculogenesis process: angioblast differentiation, proliferation, migration, endothelial cell-cell adhesion, and vascular morphogenesis can all be evaluated.
ES cells, which are derived from the inner cell mass of mouse blastocysts, are maintained in vitro as totipotent stem cells by culture in the presence of the cytokine leukemia inhibitory factor (LIF). When LIF is removed, the cells spontaneously undergo in vitro differentiation, resulting in the formation of embryo- 
like structures called embryoid bodies that have the potential to generate all embryonic cell lineages. Blood island formation and many aspects of normal endothelial differentiation and growth, leading to the formation of vascular channels, have been reported during ES-derived embryoid body development (Doetschman et al, 1985; Risau et al, 1988; Wang et al, 1992). Microscopic analysis has revealed that the vascular structures found within the walls of cystic embryoid bodies consist of endothelial cells that form tubular channels with typical endothelial junctions (Wang et al, 1992). In addition, these channels were found to connect cavernous areas that occasionally contain hematopoietic cells, evoking a primitive vasculature (Wang et al, 1992). More recent studies have indicated that endothelial development within ESderived embryoid bodies follows an ordered sequence of genetic events that recapitulates murine vasculogenesis in vivo and leads to the formation of vascular structures evoking a primitive vascular network (Vittet et al, 1996). Up-regulation of the expression of vascular adhesion receptors such as intercellular adhesion molecule-1 (ICAM-1) and vascular cell adhesion molecule (VCAM) in response to inflammatory mediators was observed in embryoid bodies, indicating the presence of functional endothelial cells (Heyward et al, 1995). Endothelial differentiation and further vascular morphogenesis was observed regardless of the cell culture procedure used to obtain embryoid bodies: suspension culture (Risau et al, 1988; Wang et al, 1992), culture in semisolid medium (Vittet et al, 1996), ES cell aggregation in hanging drops (Goumans et al, 1999), or the spinner flask technique (Wartenberg et al, 1998). These observations indicate that this in vitro system contains most of the endothelial differentiation program and probably reflects the events taking place during in vivo endothelial differentiation in the embryo, which constitutes a significant technical advance for the study of vasculogenesis in a complex tissue environment.

Indeed, genetic modifications can be easily introduced into totipotent ES cells. The differentiation of genetically modified ES cells, in which gain-offunction or loss-of-function mutations have been introduced, offers excellent alternatives to in vivo studies on transgenic animals to analyze the consequences of specific mutations on the process of vascular development, especially when these mutations are lethal to embryos (Bautch et al, 2000; Schuh et al, 1999; Vittet et al, 1997). Analysis of flk-1/- ES cell differentiation in vitro has been valuable for determining that flk-1 deficiency does not affect endothelial differentiation but rather impairs subsequent endothelial cell migration and organization into a vascular network (Schuh et al, 1999), issues that cannot be easily addressed in flk-1-deficient embryos. Similar in vitro differentiation experiments performed with heterozygous or homozygous VEGF-A mutant ES cells recently allowed the characterization of the stagespecific differentiation step at which vasculogenesis is blocked because of VEGF-A deficiency (Bautch et al, 2000). ES-derived embryoid bodies may also be useful for the development of genetically manipulated endothelial cell lines carrying gene mutations that are embryonically lethal (Balconi et al, 2000). Indeed, purified endothelial cell progenitors and endothelial cells can be easily separated from embryoid bodies at different maturation steps (Balconi et al, 2000; Hirashima et al, 1999).

In addition, endothelial differentiation in ES-derived embryoid bodies was found to be sensitive to both angiogenic and antiangiogenic agents (Sauer et al, 2000; Vittet et al, 1996; Wartenberg et al, 1998). Thus, the ES/EB model also appears particularly useful for the identification of factors potentially involved in the regulation of angioblast differentiation and further blood vessel formation in a three-dimensional tissue context.

Other experiments, performed by plating embryoid bodies primarily grown in suspension culture for 3 to 5 days onto gelatinized dishes or onto Matrigel, showed the formation of endothelial outgrowths characteristic of sprouting angiogenesis (Bielinska et al, 1996; Zhang et al, 1998). These observations indicate that the ES/EB system can also recapitulate some aspects of the angiogenic process and that this model appears to provide a unique in vitro system to gain further insight into the molecular and cellular mechanisms driving blood vessel formation.

\section{Angiogenesis Models}

Angiogenesis was first observed in vitro by Folkman and Haudenschild (1980) 20 years ago. After longterm culture of capillary endothelial cells, these authors observed the spontaneous organization of these cells into capillary-like structures (CLS). The presence of a lumen within these CLS was confirmed by phase contrast microscopy and transmission electron micrography. This report of angiogenesis in a culture dish provided the basis for the definition of in vitro endothelial angiogenesis: all the subsequently published assays referred to the presence of a lumen in the CLS as a criterion for the validation of an in vitro model. From a physiological point of view, an ideal in vitro model would take into account all the representative steps of in vivo angiogenesis, from detachment of endothelial cells from the vascular wall to final tubular morphogenesis, maturation, and connection to a functional vascular network. Furthermore, it should be rapid, easy to use, reproducible, and easily quantifiable (eg, CLS length, area covered by the capillary-like network, number of tubes, and complexity of the network). Depending on the way the cells reorganize, the assays described to date can be roughly classified into two categories represented in Figures 2 and 3: two-dimensional (when the cells develop tubular structures on the surface of the substrate) and threedimensional (when the cells invade the surrounding matrix consisting of a biogel) assays. Most published in vitro angiogenesis assays are variations of the models listed in Table 1. 


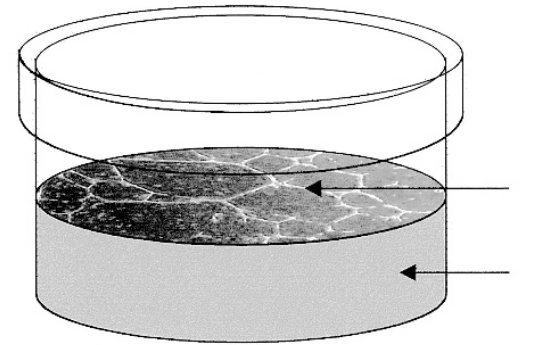

A. Two-dimensional, short term assay

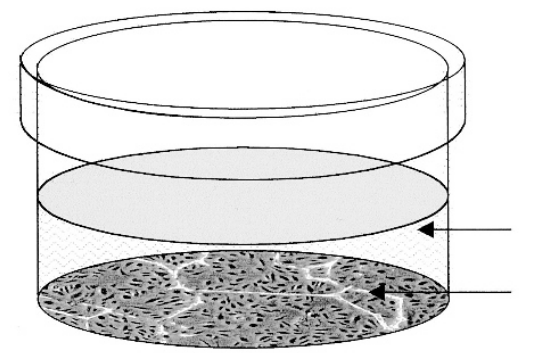

Culture medium

CLS

B. Two-dimensional, long term assay

Figure 2.

Schematic representation of two-dimensional assays. A, Two-dimensional short term assay. Capillary-like structures (CLS) develop on the surface of a gel and adopt a planar configuration. B, Two-dimensional long term assay. CLS spontaneously develop on the bottom of the dish after several days or weeks of culture.

\section{Two-Dimensional Models}

Two-dimensional models refer to those in which the planar organization of the cells lies parallel to the surface of the culture plate (Fig. 2; Vernon and Sage, 1995). In such assays, endothelial cells are seeded onto plastic culture dishes that have eventually been coated with adhesive proteins (Feder et al, 1983; Ingber and Folkman, 1989b; Madri and Williams, 1983; Pelletier et al, 2000). Alternatively, they can be loaded on top of a gel made of either collagen, fibrin, or Matrigel (Kubota et al, 1988; Vernon et al, 1995; Vailhé et al, 1997). Many reports state that CLS formation could be observed spontaneously in longterm planar cultures (Feder et al, 1983; Folkman and Haudenschild, 1980). Later, it was observed and well documented in these two-dimensional models that distinct extracellular matrix components can promote CLS formation. Madri and Williams (1983) observed that endothelial cells either proliferate when seeded on Type I or III collagen or differentiate when seeded on Type IV/V collagen. Kubota et al (1988) showed that Matrigel, a laminin-rich matrix, promoted the rapid formation of CLS. Ingber and Folkman (1989b) demonstrated that CLS formation could be induced in planar cultures and modulated by variable substrates, such as fibronectin, collagen IV, or gelatin, depending on the density of the coating. They and others demonstrated that the biomechanical tension between endothelial cells and matrix may serve to regulate capillary development (Davis and Camarillo, 1995;

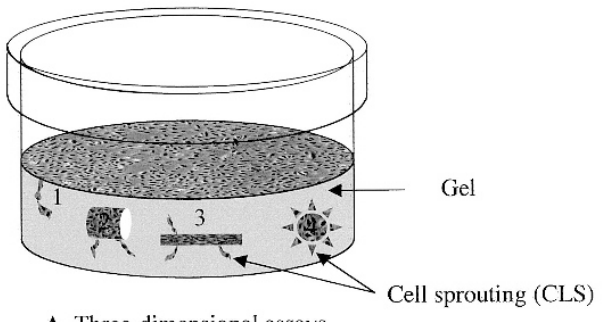

A. Three-dimensional assays

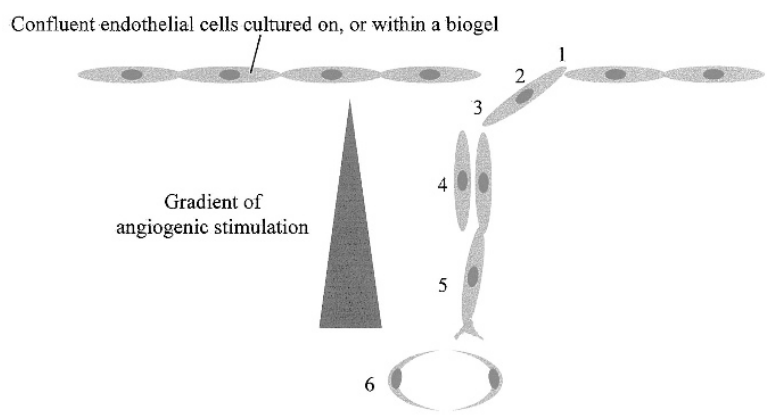

B.

$1:$ Activation of endothelial cells

(cytokines, hypoxia, extracellular matrix components)

2: Limited proteolysis of the matrix

(plasmin, metalloproteases)

$3:$ Modification of cell cell contacts

(cell adhesion molecules : integrins, cadherins, PECAM-1...)

4 : Cell proliferation (angiogenic growth factors)

5 : Migration

(chemokines, extracellular matrix, integrins)

$6:$ Morphological differentiation and tubulogenesis

(cytoskeleton, mechanical forces, cell-cell adhesion molecules)

\section{Figure 3.}

Schematic representation of three-dimensional assays. A, Three-dimensional assays: 1, activated endothelial cells seeded on a gel can invade the underlying matrix and form CLS; 2, vascular explants embedded in gel give rise to capillary sprouts; 3 , cells sandwiched between two layers of gels migrate in the surrounding matrix and form CLS; 4 , cells attached to microbeads or cell aggregates seeded in gels generate CLS. B, Molecular mechanisms that may be involved during in vitro CLS formation in three-dimensional assays. Note that in most in vitro assays, CLS are rapidly destroyed following step 6, because of the lack of maturation of the CLS.

Ingber and Folkman, 1989a; Vernon and Sage, 1995). Based on results obtained with Matrigel and collagen gels, Vernon and collaborators (Sage and Vernon, 1994; Vernon and Sage, 1995; Vernon et al, 1992, 1995) proposed that mechanical forces exerted by the cells onto the matrix drive its reorganization into cords and subsequent CLS formation. We and others observed that, when endothelial cells were seeded on fibrin, they reorganized into CLS (Olander et al, 1985; Vailhé et al, 1997). We showed that the mechanical properties of fibrin were pivotal parameters in inducing CLS formation in this system (Vailhé et al, 1997), because varying the concentration of fibrin within the gels (eg, the mechanical properties) modified the morphological behavior of the endothelial cells. However, fibrin degradation products are angiogenic (Thompson et al, 1985), and the structure of fibrin per se also plays a role (Chalupowicz et al, 1995; Sporn et 


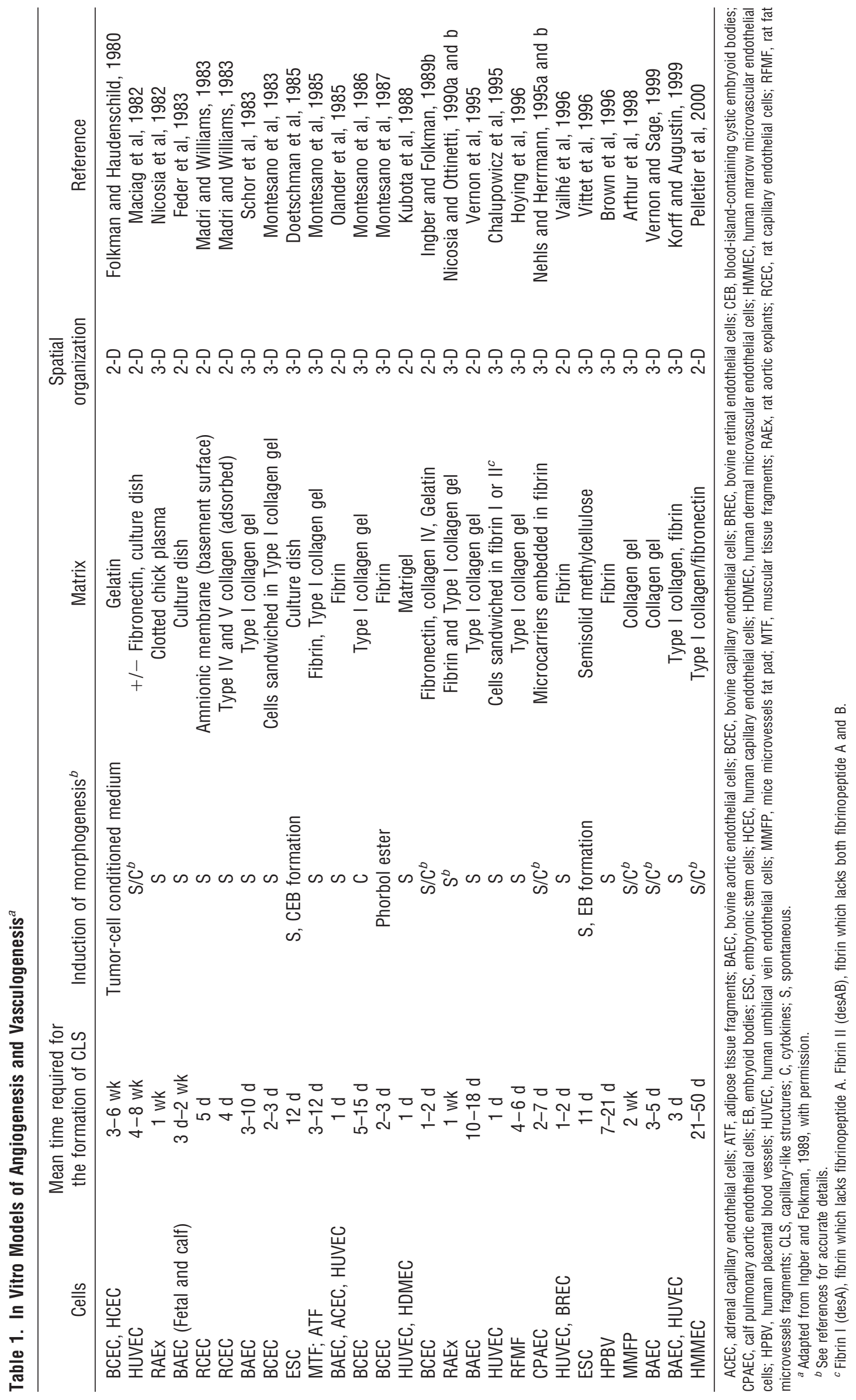


al, 1995). Thus, it is now recognized that the mechanical signals sensed by cells from the substrate depend on the concentration and biochemical composition of the matrix and regulate the formation of CLS in twodimensional models. These assays can be subdivided into two groups: short-term (Ingber and Folkman, 1989b; Kubota et al, 1988; Madri and Williams, 1983; Vailhé et al, 1997) and long term (Feder et al, 1983; Folkman and Haudenschild, 1980; Maciag et al, 1982; Pelletier et al, 2000; Vernon et al, 1995) twodimensional cultures (Fig. 2).

In short-term models, CLS are observed within 1 to 3 days of culture, and cells require subconfluence to form networks (Vailhé et al, 1997). Thus, in such systems, the number of cells seeded (ie, cell density), cell proliferation, and the concentration and biochemical composition of the matrix are determining parameters. Endothelial cells must be seeded sparsely and proliferation should be limited in order to prevent cells from reaching confluence, a condition preventing rapid CLS formation (Vailhé et al, 1997). When necessary (on fibrin and collagen gels for example), cell proliferation can be limited by lowering serum concentration in the culture medium. However, it has been shown by Kubota et al (1988) that when cells are seeded on Matrigel they no longer proliferate. Furthermore, it should be noted that cell migration may not be necessary to form CLS when cells are cultured on gelified basement membrane matrices (Manoussaki et al, 1996). In this specific situation, cellular reorganization is dependent on proteolytic degradation of the matrix (Dubois-Stringfellow et al, 1994; Vailhé et al, 1998) and on cellular forces exerted on the substrate. If the proteolytic activity of the cells is blocked or, conversely, excessive, then CLS formation is inhibited. Thus, one should be aware that short-term cultures (24-48 hr) essentially recapitulate the morphogenesis step of angiogenesis but do not take into account the proliferation and migration steps. Furthermore, once CLS are formed on gels, they often quickly detach from the matrix because of gel disruption by cellular proteases, therefore rendering it difficult to maintain CLS over longer periods of time (Vailhé et al, 1998).

In long-term cultures, the process and the factors involved in spontaneous CLS formation are much less characterized (Vernon et al, 1995); the CLS develop on top of a confluent monolayer of cells (Vernon et al, 1995), and the morphogenic pathway may require cellular synthesis of extracellular matrix (Sage and Vernon, 1994). These models are less convenient for screening the angiogenic activity of molecules than the short-term assays because the CLS are not systematically observed and only a few cells undergo the process of morphological differentiation. Therefore, they lack a strong reproducibility. However, they are more convenient for the observation of stable tubular structures forming slowly over a long period of culture. Iruela-Arispe et al (1991) and Iruela-Arispe and Sage (1993) have developed a method to isolate the cell populations which exhibit this spontaneous tubular phenotype in long-term cultures. One strength of this approach is the development of subcultures which contain mostly angiogenic cells; it allows the specific analysis of cellular and molecular characteristics of activated endothelial cells (Iruela-Arispe and Sage, 1993; Thommen et al, 1997). It is noticeable that in both short-term and long-term two-dimensional models, few coculture systems have been developed. Recently, Pelletier et al (2000) described a long-term model of spontaneous human bone marrow angiogenesis, where pericytes are associated with the development of CLS, allowing the study of heterotypic cellular interactions during tubulogenesis.

Two-dimensional angiogenesis models have thus significantly increased our understanding of the role of extracellular matrix in vascular morphogenesis, but they obviously do not reflect all steps of physiological angiogenesis. Two-dimensional models lack the third dimension; yet, as discussed by Vernon and Sage (1995), the pattern of cellular organization observed in these assays could be representative of intussusceptive rather than sprouting angiogenesis (for a review on the mechanisms of angiogenesis and vasculogenesis, see Carmeliet, 2000; Risau, 1997). Despite this undetermined aspect, two-dimensional models (Table 1) are in general simple, designed from isolated cells, and particularly convenient for screening in vitro activity of angiostatic molecules. They can also be used to assess the ultrastructure of the CLS (Banerjee, 1998; Banerjee and Martinez, 1998), the synthesis of matrix by endothelial cells, or the role of cell adhesion molecules in the tubular morphogenesis process (Gamble et al, 1993). The two-dimensional fibrin model allowed the investigation of the putative role of the hemostatic system on angiogenesis (for review, see Browder et al, 2000). Among all the twodimensional models, the only one standardized enough to permit satisfactory interlab experimental comparisons is still, in our opinion, the short-term assay on Matrigel. The Matrigel composition is not completely characterized (Zimrin et al, 1995), but it appears highly consistent because the results obtained are highly reproducible. It has allowed the screening of angiostatic molecules (Beckner and Liotta, 1996; Kuzuya and Kinsella, 1994; Morales et al, 1995; Stoltz et al, 1996a, 1996b; Wiederman et al, 1996) and the functional characterization of endothelial cell lines (Bauer et al, 1992; Hughes, 1996). The investigation of the putative role of cell adhesion molecules such as E-selectin (Gerritsen et al, 1996), PECAM-1 (Sheibani et al, 1997), cadherin-5 (Matsumura et al, 1997), and that of proteases (Schnaper et al, 1995) in tube formation has also benefited from this assay. Extracellular protein synthesis, vessel maturation (Haralabopoulos et al, 1994), the role of glycation products in diabetes (Yamagishi et al, 1997 and 1999) and that of matricellular proteins in angiogenesis (Dawson et al, 1997; DiPietro et al, 1994) have been studied as well using the Matrigel assay. 


\section{Three-Dimensional Models}

Three-dimensional angiogenesis assays are based on the capacity of activated endothelial cells to invade three-dimensional substrates (Fig. 3). The matrix may consist of collagen gels, plasma clot, purified fibrin, Matrigel, or a mixture of these proteins with others. The culture medium may be added within the gel before polymerization or on top of the gel.

It is possible to embed and culture vascular explants such as aortic rings in gelified matrices and then to observe endothelial cells sprouting from the intima and forming CLS (Nicosia et al, 1982; Nicosia and Ottinetti, 1990a, 1990b). The model developed by Nicosia and its variations are still extensively used (Arthur et al, 1998; Brown et al, 1996; Hoying et al, 1996; Zhu et al, 2000). They closely fulfill the optimal conditions for an in vitro model because they allow the preservation of the vessel architecture during the in vitro assay and thus are close to an "ex vivo" model. They can be adapted to quantify angiogenic or angiostatic activities (Nissanov et al, 1995) or to study extracellular matrix reorganization during morphogenesis (Nicosia and Madri, 1987). However, the dissection of the precise role of each cell type (fibroblasts, pericytes, smooth muscle cells, endothelial cells) in the sequence of events leading to tubular morphogenesis is not easy.

Alternatively, one can observe the morphogenic response of isolated endothelial cells that have been seeded on or in gels. When confluent cells cultured on gels are stimulated by cytokines such as basic fibroblast growth factor (bFGF) or by phorbol esters, they invade the underlying gel and form CLS, switching from a planar confluent configuration to a differentiated three-dimensional one (Montesano and Orci, 1985; Montesano et al, 1986). Cells can also be directly overlaid by gels (Schor et al, 1983) or sandwiched between two gel layers before the polymerization (Chalupowicz et al, 1995; Montesano et al, 1983). In other assays, cells are seeded in gels before polymerization, either dispersed (Bayless et al, 2000; Madri et al, 1988), clustered as spheroids (Korff and Augustin, 1999), aggregated (Nicosia et al, 1986; Vernon and Sage, 1999), or attached onto microcarrier beads (Nehls and Drenckhan, 1995a, 1995b). The three-dimensional models are closer to the in vivo environment than the two-dimensional ones, because they take into account more steps of angiogenesis. In fact, depending on the culture media composition (percentage of serum, addition of cytokines), cells can be induced to sprout, proliferate, migrate, or differentiate in the 3-D configuration. Because the biogels are polymers, the concentration and the biochemical conditions of the matrix polymerization must be carefully defined because they may affect the density and the mechanical properties of the substrate (Ferrenq et al, 1997), leading to either proliferative, migratory, or tubular endothelial cell phenotypes (Nehls and Herrmann, 1996). Furthermore, as discussed above with the two-dimensional models developed on gels, proteolysis of the matrix must be controlled (Montesano et al, 1987) and the use of exogenous antiproteases may be required to limit gel degradation (Zhu et al, 2000). From this point of view, one clear advantage of the collagen matrix, compared with fibrin, is that it offers a better resistance to endothelial cell proteases, providing a better substrate than fibrin for long-term observations. Three-dimensional models have provided great advances in the understanding of angiogenesis. In particular, Montesano et al (1986) observed that bFGF induced a confluent monolayer of endothelial cells to form CLS in collagen gels, demonstrating the in vitro angiogenic properties of this factor. In addition, they showed that phorbol ester induced cellular invasion of collagen (Montesano and Orci, 1985) or fibrin matrices (Montesano et al, 1987) and characterized the synergistic properties of bFGF and VEGF (Pepper et al, 1992) as well as the biphasic effect of TGF- $\beta 1$ on angiogenesis (Pepper et al, 1993). Three-dimensional models thus appear particularly appropriate for studying the effects of cytokines (Montesano et al, 1994; Montesano and Pepper, 1998; Pepper et al, 1994, 1996), the role of metalloproteases (Trochon et al, 1998), and that of the fibrinolytic pathway (Dubois-Stringfellow et al, 1994; Iwasaka et al, 1996; Koolwijk et al, 1996; Kroon et al, 1999; Lu et al, 1996; Van Hinsbergh et al, 1997) during tubulogenesis. Furthermore, they allowed the study of apoptosis (Korff and Augustin, 1998; Kuzuya et al, 1999; Schönherr et al, 1999) and showed the importance of the configuration and composition of the substrate (Nehls and Herrmann, 1996), the role of cell adhesion molecules (Bach et al, 1998; Bayless et al, 2000; Davis and Camarillo, 1996; Gamble et al, 1993; Trochon et al, 1996; Yang et al, 1999), and the effect of hypoxia (Phillips et al, 1995). They were also instrumental in the screening of angiogenic and angiostatic molecules (Bouloumié et al, 1998; Clapp et al, 1993; Koblizek et al, 1998; Papapetropoulos et al, 1997, Vasse et al, 1999).

Another important parameter can be investigated under the three-dimensional configuration: the bioavailability of angiogenic factors. The distance between the cells and the culture medium generates a gradient of diffusion of nutrients, oxygen, and stimulating factors. This is the case when the cells are seeded inside a gel (or sandwiched between two layers of gels) that is subsequently covered by culture medium. This gradient may represent what occurs during angiogenesis in vivo. Helmlinger et al (2000) recently demonstrated, on the basis of a sandwich system of collagen gels, that paracrine VEGF-induced morphogenesis of HUVECs depends on the distance of HUVECs from the edge of the sandwich culture. The cells retain their monolayer configuration at a distance of 0 to $2 \mathrm{~mm}$ from the edge of the sandwich, whereas a cell network is fully formed at the most hypoxic inner side of the sandwich (10-12 $\mathrm{mm}$ from the edge). This example shows that the three-dimensional configuration most completely models events occurring during angiogenesis in vivo: cell proliferation, migration, and tubulogenesis upon a gradient of nutrients and cytokines. 


\section{Future Perspectives}

The first well-defined in vitro models of vascular morphogenesis were described in the eighties (Table 1). However, as previously discussed by Jain et al (1997), the origin and passage number of endothelial cells, the nature of the substrates (extracellular matrices), the angiogenic agents, and the levels of endotoxin have not been standardized enough to permit quantitative interlab comparison of these in vitro assays. Thus, one important goal would certainly be to standardize these assays in a more accurate way. To develop models which reflect more closely the in vivo situation is another important goal for the future. Recent data (Helmlinger et al, 2000; Korff and Augustin, 1999; Pelletier et al, 2000; Vernon and Sage, 1999) show that development of in vitro models remains an active and promising approach for identifying factors involved in vascular morphogenesis (Kahn et al, 2000). The availability of genetically modified cells from transgenic or knockout mice, and the preparation of cells transfected with inducible vectors should bring a new potential to these models; it is now possible to use these genetically modified cells to investigate in vitro the precise contribution of a gene to the vasculogenesis/angiogenesis process (Balconi et al, 2000). Conversely, gene expression profiling can be studied during in vitro formation of tubelike structures, providing some new insight into the potential role of new molecules and mechanisms in angiogenesis (Kahn et al, 2000; Pröls et al, 1998). It is remarkable to consider that most of the research to date has been focused on the elucidation of the mechanisms involved in vascular morphogenesis per se, but very little on the mechanisms implicated in the involution of the capillaries. Further investigation in this area may also give rise to useful new information. The model developed by Nicosia (Nicosia et al, 1982; Nicosia and Ottinetti, 1990a, 1990b) is, to our knowledge, the only available morphogenesis model adapted to the study of regression, remodeling, and involution of capillaries similarly to the context of wound repair (Zhu et al, 2000). Recently, Schechner et al (2000) described a very interesting method for grafting in vivo CLS which were preformed in vitro in collagen/fibronectin gels. Such "ex vitro" techniques are very promising for the study of vascular remodeling and the grafting of genetically modified capillaries.

In conclusion, in vitro vasculogenesis and angiogenesis models will undoubtedly benefit from the recent availability of cells derived from genetically modified animals and up-to-date techniques for studying the mechanism of action of factors regulating vascular morphogenesis.

\section{Acknowledgements}

We thank Dr. Jonathan Lamarre for his critical comments about the manuscript.

\section{References}

Adams JC and Tucker RP (2000). The thrombospondin type 1 repeat (TSR) superfamily: Diverse proteins with related roles in neuronal development. Dev Dyn 218:280-299.

Arthur WT, Vernon RB, Sage EH, and Reed MJ (1998). Growth factors reverse the impaired sprouting of microvessels from aged mice. Microvasc Res 55:260-270.

Ashton AW, Yokota R, John G, Zhao S, Suadicani SO, Spray DC, and Ware JA (1999). Inhibition of endothelial cell migration, intercellular communication, and vascular tube formation by thromboxane $A_{2}$. J Biol Chem 274:35562-35570.

Auerbach W and Auerbach R (1994). Angiogenesis inhibition: A review. Pharmacol Ther 63:265-311.

Bach TL, Barsigian C, Chalupowicz DG, Busler D, Yaen CH, Grant DS, and Martinez J (1998). VE-Cadherin mediates endothelial cell capillary-tube formation in fibrin and collagen gels. Exp Cell Res 238:324-334.

Bader BL, Rayburn H, Crowley D, and Hynes RO (1998). Extensive vasculogenesis, angiogenesis, and organogenesis precede lethality in mice lacking all alpha $v$ integrins. Cell 95:507-519.

Balconi G, Spagnuolo R, and Dejana E (2000). Development of endothelial cell lines from embryonic stem cells: A tool for studying genetically manipulated endothelial cells in vitro. Arterioscler Thromb Vasc Biol 20:1443-1451.

Banerjee DK (1998). Angiogenesis: Characterization of a cellular model. P R Health Sci J 17:327-333.

Banerjee DK and Martinez JA (1998). Microvascular endothelial cells from adrenal medulla: A model for in vitro angiogenesis. In: Maragoudakis ME, editor. Angiogenesis: Models, modulators, and clinical implications. New York: Plenum Press, 7-18.

Bauer J, Margolis M, Schreiner C, Edgell CJ, Azizkhan J, Lazarowski E, and Juliano RL (1992). In vitro model of angiogenesis using a human endothelium-derived permanent cell line: Contributions of induced gene expression, G-proteins, and integrins. J Cell Physiol 153:437-449.

Bautch VL, Redick SD, Scalia A, Harmaty M, Carmeliet P, and Rapoport R (2000). Characterization of the vasculogenic block in the absence of vascular endothelial growth factor-A. Blood 95:1979-1987.

Bayless KJ, Salazar R, and Davis GE (2000). RGD-dependent vacuolation and lumen formation observed during endothelial cell morphogenesis in three-dimensional fibrin matrices involves the $\alpha \vee \beta 3$ and $\alpha 4 \beta 1$ integrins. Am J Pathol 156:16731683.

Beck L and D'Amore PA (1997). Vascular development: Cellular and molecular regulation. FASEB J 11:365-373.

Beckner ME and Liotta LA (1996). AAMP, a conserved protein with immunoglobulin and WD40 domains, regulates endothelial tube formation in vitro. Lab Invest 75:97-107.

Benjamin LE, Hemo I, and Keshet E (1998). A plasticity window for blood vessel remodelling is defined by pericyte coverage of the preformed endothelial network and is regulated by PDGF-B and VEGF. Development 125:1591-1598.

Bielinska M, Narita N, Heikinheimo M, Porter SB, and Wilson DB (1996). Erythropoiesis and vasculogenesis in embryoid bodies lacking visceral yolk sac endoderm. Blood 88:37203730 . 
Bouloumié A, Drexler HCA, Lafontan M, and Busse R (1998). Leptin, the product of $\mathrm{Ob}$ gene, promotes angiogenesis. Circ Res 83:1059-1066.

Brooks PC, Clark RAF, and Cheresh DA (1994a). Requirement of vascular integrin $\alpha \vee \beta 3$ for angiogenesis. Science 264:569-571.

Brooks PC, Montgomery AMP, Rosenfeld M, Reisfeld RA, Hu T, Klier G, and Cheresh DA (1994b). Integrin $\alpha \vee \beta 3$ antagonists promote tumor regression by inducing apoptosis of angiogenic blood vessels. Cell 79:1157-1164.

Brooks PC, Strömblad S, Klemke R, Visscher D, Sarkar FH, and Cheresh DA (1995). Anti-integrin $\alpha \vee \beta 3$ blocks human breast cancer growth and angiogenesis in human skin. J Clin Invest 96:1815-1822.

Browder T, Folkman J, and Pirie-Sheperd S (2000). The hemostatic system as a regulator of angiogenesis. J Biol Chem 275:1521-1524

Brown KJ, Maynes SF, Bezos A, Maguire DJ, Ford MD, and Parish CR (1996). A novel in vitro assy for human angiogenesis. Lab Invest 75:539-555.

Carmeliet P (2000). Mechanisms of angiogenesis and arteriogenesis. Nat Med 6:389-395.

Carmeliet P, Ferreira V, Breier G, Pollefeyt S, Kieckens L, Gertsenstein M, Fahrig M, Vandenhoeck A, Harpal K, Eberhardt C, Declercq C, Pawling J, Moons L, Collen D, Risau W, and Nagy A (1996). Abnormal blood vessel development and lethality in embryos lacking a single VEGF allele. Nature 380:435-439.

Carmeliet P, Lampugnani MG, Moons L, Brevario F, Compernolle V, Bono F, Balconi G, Spagnuolo R, Oostuyse B, Dewerchin M, Zanetti A, Angellilo A, Mattot V, Nuyens D, Lutgens E, Clotman F, de Ruiter MC, Gittenberg-de Groot A, Poelmann R, Lupu F, Herbert JM, Collen D, and Dejana $E$ (1999). Targeted deficiency or cytosolic truncation of the VE-cadherin gene in mice impairs VEGF-mediated endothelial survival and angiogenesis. Cell 98:147-157.

Chalupowicz G, Chowdhury ZA, Bach TL, Barsigian C, and Martinez J (1995). Fibrin II induces endothelial cell capillary tube formation. J Cell Biol 130:207-215.

Claesson-Welsh L, Welsh M, Ito N, Anand-Apte B, Soker S, Zetter B, O'Reilly M, and Folkman J (1998). Angiostatin induces endothelial cell apoptosis and activation of focal adhesion kinase independently of the integrin-binding motif RGD. Proc Natl Acad Sci USA 95:5579-5583.

Clapp C, Martial JA, Guzman RC, Rentier-Delure F, and Weiner RI (1993). The 16-kilodalton N-terminal fragment of human prolactin is a potent inhibitor of angiogenesis. Endocrinology 133:1292-1299.

Davis GE and Camarillo CW (1995). Regulation of endothelial cell morphogenesis by integrins, mechanical forces, and matrix guidance pathways. Exp Cell Res 216:113-123.

Davis GE and Camarillo CW (1996). An $\alpha 2 \beta 1$ integrindependent pinocytic mechanism involving intracellular vacuole formation and coalescence regulates capillary lumen and tube formation in three-dimensional collagen matrix. Exp Cell Res 224:39-51.

Dawson DW, Pearce SF, Zhong R, Silverstein RL, Frazier WA, and Bouck NP (1997). CD36 mediates the in vitro inhibitory effects of thrombospondin-1 on endothelial cells. J Cell Biol 138:707-717.
DeLisser H, Christofidou-Solomidou M, Strieter RM, Burdick MD, Robinson CS, Wexler RS, Kerr JS, Garlanda C, Merwin JR, Madri JA, and Albelda SM (1997). Involvement of endothelial PECAM-1/CD31 in angiogenesis. Am J Pathol 151: 671-677

DiPietro LA, Nebgen DR, and Polverini PJ (1994). Downregulation of endothelial cell thrombospondin 1 enhances in vitro angiogenesis. J Vasc Res 31:178-185.

Doetschman TC, Eistetter H, Katz M, Schmidt W, and Kemler $\mathrm{R}$ (1985). The in vitro development of blastocyst-derived cell lines: Formation of visceral yolk sac, blood islands and mycardium. J Embryol Exp Morphol 87:27-45.

Dubois-Stringfellow N, Jonczyk A, and Bautch VL (1994). Perturbations in the fibrinolytic pathway abolish cyst formation but not capillary-like organization of cultured murine endothelial cells. Blood 83:3206-3217.

Feder J, Marasa JC, and Olander JV (1983). The formation of capillary-like tubes by calf aortic endothelial cells grown in vitro. J Cell Physiol 116:1-6.

Ferrara N, Carver-Moore K, Chen H, Dowd M, Lu L, O'Shea KS, Powell-Braxton L, Hillan KJ, and Moore MW (1996). Heterozygous embryonic lethality induced by targeted inactivation of the VEGF gene. Nature 380:439-442.

Ferrenq I, Tranqui L, Vailhé B, Gumery PY, and Tracqui P (1997). Modelling biological gel contraction by cells: Mechanocellular formulation and cell traction force quantification. Acta Biotheor 45:267-293.

Flamme I, Baranowski A, and Risau W (1993). A new model of vasculogenesis and angiogenesis in vitro as compared with vascular growth in the avian area vasculosa. Anat Rec 237:49-57.

Flamme I and Risau W (1992). Induction of vasculogenesis and hematopoiesis in vitro. Development 116:435-439.

Folkman J (1995). Angiogenesis in cancer, vascular, rheumatoid and other disease. Nat Med 1:27-31.

Folkman $\mathrm{J}$ and Haudenschild C (1980). Angiogenesis in vitro. Nature 288:551-556.

Folkman J and Shing Y (1992). Angiogenesis. J Biol Chem 267:10931-10934.

Fong $\mathrm{GH}$, Rossant J, Gertsenstein M, and Breitman ML (1995). Role of the flt-1 receptor tyrosine kinase in regulating the assembly of the vascular endothelium. Nature 376:6670.

Gamble JR, Matthias LJ, Meyer G, Kaur P, Russ G, Faul L, Berndt MC, and Vadas MA (1993). Regulation of in vitro capillary tube formation by anti-integrin antibodies. J Cell Biol 121:931-943.

Gerritsen ME, Shen CP, Atkinson WJ, Padgett RC, Gimbrone MA, and Milstone DS (1996). Microvascular endothelial cells from E-selectin-deficient mice form tubes in vitro. Lab Invest 75:175-184.

Gory-Faure S, Prandini MH, Pointu H, Roullot V, PignotPaintrand I, Vernet M, and Huber P (1999). Role of vascular endothelial-cadherin in vascular morphogenesis. Development 126:2093-2102.

Goumans M-J, Zwijsen A, Van Rooijen MA, Huylebroeck D, Roelen BAJ, and Mummery CL (1999). Transforming growth factor- $\beta$ signalling in extraembryonic mesoderm is required for yolk sac vasculogenesis in mice. Development 126:34733483. 
Haralabopoulos GC, Grant DS, Kleinman HK, Lelkes PI, Papaioannou SP, and Maragoudakis ME (1994). Inhibitors of basement membrane collagen synthesis prevent endothelial cell alignment in Matrigel in vitro and angiogenesis in vivo. Lab Invest 71:575-582.

Helmlinger G, Endo M, Ferrara N, Hlatky L, and Jain RK (2000). Formation of endothelial cell networks. Nature 405: $139-141$.

Heyward SA, Dubois-Stringfellow N, Rapoport R, and Bautch VL (1995). Expression and inducibility of vascular adhesion receptors in development. FASEB J 9:956-962.

Hirashima M, Kataoka H, Nishikawa S, Matsuyoshi N, and Nishikawa S-I (1999). Maturation of embryonic stem cells into endothelial cells in an in vitro model of vasculogenesis. Blood 93:1253-1263.

Hodivala-Dilke KM, McHugh KP, Tsakiris DA, Rayburn $\mathrm{H}$, Crowley D, Ullman-Cullere M, Ross FP, Coller BS, Teitelbaum S, and Hynes RO (1999). Beta3-integrin-deficient mice are a model for Glanzmann thrombasthenia showing placental defects and reduced survival. J Clin Invest 103:229-238.

Hoying JB, Boswell CA, and Williams SK (1996). Angiogenic potential of microvessels fragments established in threedimensional collagen gels. In Vitro Cell Dev Biol 32:409-419.

Hoying JB and Williams SK (1996). Effects of basic fibroblast growth factor on human microvessel endothelial cell migration on collagen I correlates inversely with adhesion and is cell density dependent. J Cell Physiol 168:294-304.

Hughes SE (1996). Functional characterization of the spontaneously transformed human umbilical vein endothelial cell line ECV304: Use in an in vitro model of angiogenesis. Exp Cell Res 225:171-185.

Ingber DE and Folkman J (1989a). How does extracellular matrix control capillary morphogenesis? Cell 58:803-805.

Ingber DE and Folkman J (1989b). Mechanochemical switching between growth and differentiation during fibroblast growth factor-stimulated angiogenesis in vitro: Role of extracellular matrix. J Cell Biol 109:317-330.

Iruela-Arispe ML and Dvorak HF (1997). Angiogenesis: A dynamic balance of stimulators and inhibitors. Thromb Haemost 78:67-677.

Iruela-Arispe ML, Hasselar P, and Sage EH (1991). Differential expression of extracellular proteins is correlated with angiogenesis in vitro. Lab Invest 64:174-186.

Iruela-Arispe ML and Sage EH (1993). Endothelial cells exhibiting angiogenesis in vitro proliferate in response to TGFbeta 1. J Cell Biochem 52:414-430.

Isner JM and Asahara T (1999). Angiogenesis and vasculogenesis as therapeutic strategies for postnatal neovascularization. J Clin Invest 103:1231-1236.

Iwasaka C, Tanaka K, Abe M, and Sato Y (1996). Ets-1 regulates angiogenesis by inducing the expression of urokinase-type plasminogen activator and matrix metalloproteinase-1 and the migration of vascular endothelial cells. J Cell Physiol 169:522-531.

Jain RK, Schlenger K, Höckel M, and Yuan F (1997). Quantitative angiogenesis assays: Progress and problems. Nat Med 3:1203-1208.

Jimenez B, Volpert OV, Crawford SE, Febbraio M, Silverstein RL, and Bouck N (2000). Signals leading to apoptosis- dependent inhibition of neovascularization by thrombospondin-1. Nat Med 6:41-48.

Kahn J, Mehraban F, Ingle G, Xin X, Bryant JE, Vehar G, Schoenfeld J, Grimaldi CJ, Peale F, Drakshapuru A, Lewin DA, and Gerritsen ME (2000). Gene expression profiling in an in vitro model of angiogenesis. Am J Pathol 156:1887-1900.

Klohs WD and Hamby JM (1999). Antiangiogenic agents. Curr Opin Biotechnol 10:544-549.

Koblizek TI, Weiss C, Yancopoulos D, Deutsch U, and Risau W (1998). Angiopoietin-1 induces sprouting angiogenesis in vitro. Curr Biol 8:529-532.

Koolwijk P, Van Erck MGM, De Vree WJA, Vermeer MA, Weich HA, Hanemaajer R, and Van Hinsbergh VWM (1996). Cooperative effect of TNF $\alpha$, bFGF and VEGF on the formation of tubular structures of human microvascular endothelial cells in a fibrin matrix. Role of urokinase activity. J Cell Biol 132:1177-1188.

Korff T and Augustin HG (1998). Integration of endothelial cells in multicellular spheroids prevents apoptosis and induces differentiation. J Cell Biol 143:1341-1352.

Korff T and Augustin HG (1999). Tensional forces in fibrillar extracellular matrices control directional capillary sprouting. J Cell Sci 112:3249-3258.

Krah K, Mironov V, Risau W, and Flamme I (1994). Induction of vasculogenesis in quail blastodisc-derived embryoid bodies. Dev Biol 164:123-132.

Kroon ME, Koolwijk P, Goor HV, Weidle UH, Collen A, van der Pluijm G, and van Hinsbergh VWM (1999). Role and localization of urokinase receptor in the formation of new microvascular structures in fibrin matrices. Am J Pathol 154:17311742.

Kubota Y, Kleinman Martin GR, and Lawley TJ (1988). Role of laminin and basement membrane in the morphological differentiation of human endothelial cells into capillary-like structures. J Cell Biol 107:1589-1598.

Kuzuya M and Kinsella JL (1994). Reorganization of endothelial cord-like structures on basement membrane complex (Matrigel): Involvement of transforming growth factor $\beta 1$. J Cell Physiol 161:267-276.

Kuzuya M, Satake S, Ramos M, Kanda S, Koike T, Yoshino K, Ikeda S, and Iguchi A (1999). Induction of apoptotic cell death in vascular endothelial cells cultured in three-dimensional collagen lattice. Exp Cell Res 248:498-508.

Lu H, Mabilat C, Yeh P, Guitton JD, Li H, Pouchelet M, Shoevaert D, Legrand Y, Soria J, and Soria C (1996). Blockage of urokinase receptor reduces in vitro the motility and the deformability of endothelial cells. FEBS Lett 380:21-24.

Maciag T, Kadish L, Wilkins L, Stemerman MB, and Weinstein R (1982). Organizational behavior of human umbilical vein endothelial cells. J Cell Biol 94:511-520.

Madri JA, Pratt BM, and Tucker AM (1988). Phenotypic modulation of endothelial cells by transforming growth factor- $\beta$ depends upon the composition and organization of the extracellular matrix. J Cell Biol 106:1375-1384.

Madri JA and Williams SK (1983). Capillary endothelial cell cultures: Phenotypic modulation by matrix components. J Cell Biol 97:153-165.

Manoussaki D, Lubkin SR, Vernon RB, and Murray JD (1996). A mechanical model for the formation of vascular networks in vitro. Acta Biotheor 44:271-282. 
Matsumura T, Wolff K, and Petzelbauer P (1997). Endothelial cell tube formation depends on cadherin 5 and CD31 interactions with filamentous actin. J Immunol 158:3408-3416.

Montesano R, Mouron P, and Orci L (1985). Vascular outgrowths from tissue explants embedded in fibrin or collagen gels: A simple in vitro model of angiogenesis. Cell Biol Int Rep 9:869-875.

Montesano R and Orci L (1985). Tumor-promoting phorbol esters induce angiogenesis in vitro. Cell 42:469-477.

Montesano R, Orci L, and Vassalli JD (1983). In vitro rapid organization of endothelial cells into capillary-like network is promoted by collagen matrices. J Cell Biol 97:1648-1652.

Montesano R and Pepper MS (1998). Three-dimensional in vitro assay of endothelial cell invasion and capillary tube morphogenesis. In: Little CD, Mironov V, and Sage EH, editors. Vascular morphogenesis: In vivo, in vitro, in mente. Boston/Basel/Berlin: Birkhäuser, 79-110.

Montesano R, Pepper MS, Vassali JD, and Orci L (1987). Phorbol ester induces cultured endothelial cells to invade a fibrin matrix in the presence of fibrinolytic inhibitors. J Cell Physiol 132:509-516.

Montesano R, Vassalli JD, Baird A, Guillemin R, and Orci L (1986). Basic fibroblast growth factor induces angiogenesis in vitro. Proc Natl Acad Sci USA 83:7297-7301.

Montesano R, Vassali JD, Orci L, and Pepper MS (1994). The role of growth factors and extracellular matrix in angiogenesis and epithelial morphogenesis. In: Sizonenko PC, Augert ML, and Vassali JD, editors. Developmental endocrinology (Frontiers in Endocrinology, vol 6). Rome: Ares-Serono Symposia Publications, 43-66.

Morales DE, McGowan KA, Grant DS, Maheshwari S, Bhartiya D, Cid MC, Kleinman HK, and Schnaper HW (1995). Estrogen promotes angiogenic activity in human umbilical vein endothelial cells in vitro and in a murine model. Circulation 91:755-763.

Nehls V and Drenckhan D (1995a). A novel, microcarrierbased in vitro assay for rapid and reliable quantification of three-dimensional cell migration and angiogenesis. Microvasc Res 50:311-322.

Nehls V and Drenckhan D (1995b). A microcarrier-based cocultivation system for the investigation of factors and cells involved in angiogenesis in three-dimensional fibrin matrices in vitro. Histochem Cell Biol 104:459-466.

Nehls V and Herrmann R (1996). The configuration of fibrin clots determines capillary morphogenesis and endothelial cell migration. Microvasc Res 51:347-364.

Nicosia RF and Madri JA (1987). The microvascular extracellular matrix. Developmental changes during angiogenesis in the aortic ring-plasma clot model. Am J Pathol 128:78-90.

Nicosia RF and Ottinetti A (1990a). Growth of microvessels in serum-free matrix culture of rat aorta. Lab Invest 63:115-122.

Nicosia RF and Ottinetti A (1990b). Modulation of microvascular growth and morphogenesis by reconstituted basement membrane gel in three-dimensional cultures of rat aorta: a comparative study of angiogenesis in Matrigel, collagen, fibrin, and plasma clot. In Vitro Cell Dev Biol 26:119-128.

Nicosia RF, Tchao R, and Leighton J (1982). Histotypic angiogenesis in vitro: Light microscopic, ultrastructural, and radioautographic studies. In Vitro 18:538-549.
Nicosia RF, Tchao R, and Leighton J (1986). Interactions between newly formed endothelial channels and carcinoma cells in plasma clot cultures. Clin Exp Metastasis 4:91-104.

Nissanov J, Tuman RW, Gruver LM, and Fortunato JM (1995). Automatic vessel segmentation and quantification of the rat aortic ring assay of angiogenesis. Lab Invest 73:734-739.

Olander JV, Bremer ME, Marasa JC, and Feder J (1985). Fibrin-enhanced endothelial cell organisation. J Cell Physiol 125:1-9.

Papapetropoulos A, Garcia-Cardena G, Madri JA, and Sessa WC (1997). Nitric oxide production contributes to the angiogenic properties of vascular endothelial growth factor in human endothelial cells. J Clin Invest 100:3131-3139.

Pelletier L, Regnard J, Fellman D, and Charbord P (2000). An in vitro model for the study of human bone marrow angiogenesis: Role of hematopoietic cytokines. Lab Invest 80:501-511.

Pepper MS, Ferrara N, Orci L, and Montesano R (1992). Potent synergism between vascular endothelial growth factor and basic fibroblast growth factor in the induction of angiogenesis in vitro. Biochem Biophys Res Commun 189:824831.

Pepper MS, Montesano R, Mandriota SJ, Orci L, and Vassali JD (1996). Angiogenesis: A paradigm for balanced extracellular proteolysis during cell migration and morphogenesis. Enzyme Protein 49:138-162.

Pepper MS, Vassalli JD, Montesano R, and Orci L (1987). Urokinase-type plasminogen activator is induced in migrating capillary endothelial cells. J Cell Biol 105:2353-2541.

Pepper MS, Vassalli JD, Orci L, and Montesano R (1993). Biphasic effect of transforming growth factor- $\beta 1$ on in vitro angiogenesis. Exp Cell Res 204:356-363.

Pepper MS, Vassalli JD, Orci L, and Montesano R (1994). Angiogenesis in vitro: Cytokines interactions and balanced extracellular proteolysis. In: Maragoudakis ME, editor. Angiogenesis: Molecular biology, clinical aspects. New York: Plenum Press, 149-170.

Phillips PG, Birnby LM, and Narendran A (1995). Hypoxia induces capillary network formation in cultured bovine pulmonary microvessel endothelial cells. Am J Physiol 268:789800 .

Pröls F, Loser B, and Marx M (1998). Differential expression of osteopontin, PC4, and CEC5, a novel mRNA species, during in vitro angiogenesis. Exp Cell Res 239:1-10.

Risau W (1997). Mechanisms of angiogenesis. Nature 386: 671-674.

Risau W and Flamme I (1995). Vasculogenesis. Annu Rev Cell Dev Biol 11:73-91.

Risau W, Sariola H, Zerwes HG, Sasse J, Ekblom P, Kemler $R$, and Doetschman T (1988). Vasculogenesis and angiogenesis in embryonic-stem-cell-derived embryoid bodies. Development 102:471-478.

Sage EH (1997). Pieces of eight: Bioactive fragments of extracellular proteins as regulators of angiogenesis. Trends Cell Biol 7:182-186.

Sage EH and Vernon RB (1994). Regulation of angiogenesis by extracellular matrix: The growth and the glue. J Hypertens Suppl 12:S145-S152. 
Sauer H, Günther J, Hescheler J, and Wartenberg M (2000). Thalidomide inhibits angiogenesis in embryoid bodies by the generation of hydroxyl radicals. Am J Pathol 156:151-158.

Schechner JS, Nath AK, Zheng L, Kluger MS, Hughes CC, Sierra-Honigmann MR, Lorber MI, Tellides G, Kashgarian M, Bothwell AL, and Pober JS (2000). In vivo formation of complex microvessels lined by human endothelial cells in an immunodeficient mouse. Proc Natl Acad Sci USA 97:91919196.

Schnaper HW, Barnathan ES, Mazar A, Maheshwari S, Ellis S, Cortez SL, Baricos WH, and Kleinman HK (1995). Plasminogen activators augment endothelial cell organization in vitro by two distinct pathways. J Cell Physiol 165:107-118.

Schönherr E, O'Connell BC, Schittny J, Robenek H, Fastermann D, Fisher LW, Plenz G, Vischer P, Young MF, and Kresse $H$ (1999). Paracrine or virus-mediated induction of decorin expression by endothelial cells contributes to tube formation and prevention of apoptosis in collagen lattices. Eur J Cell Biol 78:44-55.

Schor AM, Schor SL, and Allen TD (1983). Effects of culture conditions on the proliferation, morphology and migration of bovine aortic endothelial cells. J Cell Sci 62:267-285.

Schuh AC, Faloon P, Hu QL, Bhimani M, and Choi K (1999). In vitro hematopoietic and endothelial potential of $\mathrm{flk}-1^{-/-}$ embryonic stem cells and embryos. Proc Natl Acad Sci USA 96:2159-2164.

Shalaby $F$ (1995). Failure of blood-island formation and vasculogenesis in flk-1 deficient mice. Nature 376:62-66.

Sheibani N, Newman PJ, and Frazier WA (1997). Thrombospondin-1, a natural inhibitor of angiogenesis, regulates platelet-endothelial cell adhesion molecule-1 expression and endothelial cell morphogenesis. Mol Biol Cell 8:1329-1341.

Sporn LA, Bunce LA, and Francis CW (1995). Cell proliferation on fibrin: Modulation by fibrinopeptide cleavage. Blood 86:1802-1810.

Stoltz RA, Abraham NG, and Schwartzman ML (1996a). The role of NF- $\kappa B$ in the angiogenic response of coronary microvessel endothelial cells. Proc Natl Acad Sci USA 93:28322837.

Stoltz RA, Conners MS, Gerritsen ME, Abraham NG, and Laniado-Schwartzman M (1996b). Direct stimulation of limbal microvessel endothelial cell proliferation and capillary formation in vitro by a corneal-derived eicosanoid. Am J Pathol 148:129-139.

Thommen R, Humar R, Misevic G, Pepper MS, Hahn AW, John M, and Battegay EJ (1997). PDGF-BB increases endothelial migration on cord movements during angiogenesis in vitro. J Cell Biochem 64:403-413.

Thompson WD, Campbell R, and Evans T (1985). Fibrin degradation and angiogenesis: Quantitative analysis of the angiogenic response in the chick chorioallantoic membrane. J Pathol 145:27-37.

Trochon V, Li H, Vasse M, Frankenne F, Thomaidis A, Soria J, Lu H, Gardner C, and Soria C (1998). Endothelial metalloprotease-disintegrin protein (ADAM) is implicated in angiogenesis in vitro. Angiogenesis 2:277-285.

Trochon V, Mabilat C, Bertrand P, Legrand Y, Smadja-Joffe F, Soria C, Delpech B, and Lu H (1996). Evidence of involvement of CD44 in endothelial cell proliferation, migration and angiogenesis in vitro. Int $\mathrm{J}$ Cancer 66:664-668.
Vailhé B, Lecomte M, Wiernsperger N, and Tranqui L (1998). The formation of tubular structures by endothelial cells is under the control of fibrinolysis and mechanical factors. Angiogenesis 2:331-344.

Vailhé $\mathrm{B}$, Ronot $\mathrm{X}$, Lecomte $\mathrm{M}$, Wiernsperger $\mathrm{N}$, and Tranqui $L$ (1996). Description of an in vitro angiogenesis model designed to test antiangiogenic molecules. Cell Biol Toxicol 12:341-344.

Vailhé B, Ronot X, Tracqui P, Usson $Y$, and Tranqui $L$ (1997). In vitro angiogenesis is modulated by the mechanical properties of fibrin and is related to $\alpha v \beta 3$ integrin localisation. In Vitro Cell Dev Biol 33:763-773.

Van Hinsbergh VWM, Koolwijk P, and Hanemaaijer R (1997). Role of fibrin and plasminogen activators in repair-associated angiogenesis: In vitro studies with human endothelial cells. EXS 79:391-411.

Vasse M, Pourteau J, Trochon V, Muraine M, Vannier JP, Lu H, Soria J, and Soria C (1999). Oncostatin M induces angiogenesis in vitro and in vivo. Arterioscler Thromb Vasc Biol 19:1835-1842.

Vernon RB, Angello JC, Iruela-Arispe ML, Lane TF, and Sage $\mathrm{EH}$ (1992). Reorganization of basement membrane matrices by cellular traction promotes the formation of cellular networks in vitro. Lab Invest 66:536-547.

Vernon RB, Lara SL, Drake CJ, Iruela-Arispe ML, Angello JG, Little CD, Wight TN, and Sage EH (1995). Organized type I collagen influences endothelial patterns during "spontaneous angiogenesis in vitro": Planar cultures as models of vascular development. In Vitro Cell Dev Biol 31:120-131.

Vernon RB and Sage EH (1995). Between molecules and morphology. Extracellular matrix and creation of vascular form. Am J Pathol 147:873-883.

Vernon RB and Sage EH (1999). A novel, quantitative model for study of endothelial cell migration and sprout formation within three-dimensional collagen matrices. Microvasc Res 57:118-133.

Vittet D, Buchou T, Schweitzer A, Dejana E, and Huber P (1997). Targeted null-mutation in the vascular endothelialcadherin gene impairs the organization of vascular-like structures in embryoid bodies. Proc Natl Acad Sci USA 94:62736278.

Vittet D, Prandini MH, Berthier R, Schweitzer A, MartinSisteron H, Uzan G, and Dejana E (1996). Embryonic stem cells differentiate in vitro to endothelial cells through successive maturation steps. Blood 88:3424-3431.

Wang R, Clark R, and Bautch VL (1992). Embryonic stem cell-derived cystic embryoid bodies form vascular channels: An in vitro model of blood vessel development. Development 114:303-316.

Wartenberg M, Günther J, Hescheler J, and Sauer H (1998). The embryoid body as a novel in vitro assay system for antiangiogenic agents. Lab Invest 78:1301-1314.

Wiederman CJ, Auer B, Sitte B, Reinisch N, Schratzberger P, and Kälher CM (1996). Induction of endothelial cell differentiation into capillary-like structures by substance P. Eur J Pharmacol 298:335-338.

Yamagishi SI, Kawakami T, Fujimori H, Yonekura H, Tanaka $\mathrm{N}$, Yamamoto $\mathrm{Y}$, Urayama $\mathrm{H}$, Watanabe $\mathrm{Y}$, and Yamamoto $\mathrm{H}$ (1999). Insulin stimulates the growth and tube formation of human microvascular endothelial growth factor. Microvasc Res 57:329-339. 
Yamagishi SI, Yonekura H, Yamamoto Y, Katsuno K, Sato F, Mita I, Ooka H, Satozawa N, Kawakami T, Nomura M, and Yamamoto H (1997). Advanced glycation end productsdriven angiogenesis in vitro. J Biol Chem 272:8723-8730.

Yang S, Graham J, Kahn JW, Schwartz EA, and Gerritsen ME (1999). Functional roles for PECAM-1 (CD31) and VECadherin (CD144) in tube formation assembly and lumen formation in three-dimensional collagen gels. Am J Pathol 155:887-895.

Zhang XJ, Tsung HC, Caen JP, Li XL, Yao Z, and Han ZC (1998). Vasculogenesis from embryonic bodies of murine embryonic stem cells transfected by TGF- $\beta 1$ gene. Endothelium 6:95-106.
Zhu WH, Guo X, Villaschi S, and Nicosia RF (2000). Regulation of vascular growth and regression by matrix metalloproteinases in the rat aorta model of angiogenesis. Lab Invest 80:545-555.

Zimrin AB, Villeponteau B, and Maciag T (1995). Models of in vitro angiogenesis: Endothelial cell differentiation on fibrin but not Matrigel is transcriptionally dependent. Biochem Biophys Res Commun 213:630-638. 